\title{
Influence of Individual, Organizational and System Factors on Attitude of Online Banking Users
}

\author{
Wole Olatokun and Olalekan Joseph Owoeye \\ Africa Regional Centre for Information Science (ARCIS) \\ University of Ibadan, Nigeria
}

\section{woleabbeyolatokun@yahoo.co.uk; pastorjoe4u@rocketmail.com}

\begin{abstract}
The study investigated the influence of individual, organizational and system factors on attitude among online banking users in Osun state, Nigeria. The influence of the five constructs: system and service quality, perceived risk, organizational reputation, perceived ease of use and perceived usefulness on attitude was used to determine users' intention to use online banking. Survey research design was adopted. Six hundred online banking users in five banks were selected using stratified random sampling. Data were collected using a structured questionnaire. Frequency and percentage distributions and multiple regression were analytical techniques used. The research hypotheses were tested at $0.05 \%$ level of significance. Findings revealed that the constructs - system and service quality $(\beta .127, \mathrm{p} .003)$, perceived risk ( $\beta .122, \mathrm{p} .000)$, organizational reputation $(\beta .167, \mathrm{p} .000)$, perceived ease of use $(\beta .206, \mathrm{p} .000)$ and perceived usefulness $(\beta .119, \mathrm{p} .002)$-, have a significant influence on the attitude of online banking users. Also attitude had a significant impact on the Intention to use online banking. System and service quality had the lowest weight of impact on attitude while perceived ease of use had the highest. It was concluded that individual, organizational and systems factors influence attitude toward continued use of banking. Banks should make the interface of online banking systems as friendly as possible and adopt the latest technologies that are standardized for effective and efficient internet banking transactions.
\end{abstract}

Keywords: Attitude, Online banking, System and service quality, Perceived risk, Organizational Reputation, Nigeria

\section{Introduction}

Technological advances in the banking industry have revolutionized how people manage their finances. In 1995, online banking was introduced to the public. It enables access to financial information via the Internet using personal computers, hand-held devices, kiosks, Web TVs, and cellular phones. Customers now have greater access to information, the ability to receive helpful updates and advice while reaping the benefits of convenience (Business Communications, 2007).

Material published as part of this publication, either on-line or in print, is copyrighted by the Informing Science Institute. Permission to make digital or paper copy of part or all of these works for personal or classroom use is granted without fee provided that the copies are not made or distributed for profit or commercial advantage AND that copies 1) bear this notice in full and 2) give the full citation on the first page. It is permissible to abstract these works so long as credit is given. To copy in all other cases or to republish or to post on a server or to redistribute to lists requires specific permission and payment of a fee. Contact Publisher@InformingScience.org to request redistribution permission.
Global internet access exceeded 1094

million people in December 2008 (Internet World Status, 2009), offering new markets for internet-based services such as internet banking. Internet is a technology that spreads faster than any other technology - the use of Internet is estimated to double in every hundred days (Tajudeen et al., 2006). Since the new millennium, internet banking has experienced explosive growth in many 
countries and has transformed traditional banking practice. By offering internet banking services, traditional financial institutions seek to lower operational costs, improve consumer banking services, retain consumers and expand share of customer (Internet World Status, 2009).

Before 1998, there were just a few dial-up e-mail providers in Nigeria - a couple of Internet service providers (ISPs) that operated on slow links -. For years, Nigerian Telecommunications Plc (Nitel) dominated the whole telecommunications market. E-commerce in Nigeria is just at the beginning stage. From the convenient places like homes or offices, these days, most banks offer internet banking services which enable customers to conduct banking transactions online. Today, majority of Nigerian banks offer online, real-time banking services. The area of e-commerce that has developed mostly in Nigeria mostly is e-banking. A few banks started the Automated Teller Machine Consortium in 2003 to set up ATMs across the country. Report on Internet banking system in Nigeria reveals that e-payment machinery, especially the card technology, is presently enjoying the highest popularity in Nigeria banking market (Tajudeen, et al, 2006). According to inter-switch statistics, (2010) Nigeria has 30million ATM card holders who conduct over 100 million transactions every month. Nigeria's 24 banks operate over 9,000 Automated Teller Machines across the country's 36 states and Federal Capital Territory. Also, to enhance effective security measure, banks have since early 2011 been upgrading their ATM cards from the magnetic stripe to the Euro-Visa-Master card standard, popularly known as Verve Card (Business day online, 2011). This technological device is more fraud resistant because customer data are recorded on the chip. The union of technology and finance has recorded huge success and has impacted on financial transactions positively.

\section{Background}

Banking in Nigeria today is beset by long queues, energy exacting and time-consuming, and on the whole, costly. It defeats the purpose of customer service to see the hard time that many customers go through to access banking services around the end of every month when most salaries are paid through the banks. This has resulted in the loss in potential exchanges as many people simply keep money outside the banking system to avoid the ordeal meted out to them by banks (William and Appiah, 2008; Appiah and Agyemang, 2005). Physical cash and paperwork still characterize most of the payment systems in Nigeria and remain popular in spite of the introduction of digital payment cards. The main focus of adopting digital technology by the banks, as it appears, is to network customer accounts information across branches to create business value (operational excellence) rather than customer value. In eliminating time, space and distance constraints, customizing products and services, effecting payment or cross-selling, the internet stands out as the biggest digital platform for businesses that leverage the technology. In addition, compression technologies are converting the internet's platform, the web, into a multimedia platform (Ayobami, 2009) making the internet channel a holistic interactive platform. Kolawole and Kayode (2008) also identified labour cost for banks as an incentive to introduce technology-based self-service offer to customers.

With these advantages for consumers in online banking, most Nigerian bank customers appear to be more comfortable with over-the-counter banking services than online banking and gives it little or no attention although utilizing ATMs and other digital services. Indeed, leveraging a new technological platform is not a guarantee for success as learned the hard way by many early dotcoms during the internet boom. The customer, who is at the center of strategic planning, must be understood from his or her perspective of the value offered by a given technological platform. Woodruff (2008) puts forth that the strategy of inward approach by organizations seeking improvement through quality management, reengineering and downsizing among others to gain competitive advantage must be extended to include an outward orientation towards the customeran emerging source of competitive advantage. Williamson (2006) also observes that the focus of 
research in internet banking is shifting from technological development to the user. Many an academic literature has demonstrated that a customer process enhances a business' competitive advantage (Cooper, 1992). Customer loyalty is improved through offers of superior value relative to competition (Salem, 2004).

Despite all the effort of banks at developing better and easier Internet banking systems, these systems remained largely unnoticed by customers, and certainly are under-used (Appiah and Agyemang, 2005). There is a need to analyse the factors that can affect users' attitude towards intention to use Internet banking. It is pertinent because the answer holds the clue that will help the banking industry to formulate their marketing strategies to promote new forms of Internet banking systems in the future. Another motivation came from the fact that internet banking has become popular, especially in Nigeria and other parts of African countries, for a variety of reasons. Explaining the facts that have made internet banking technology so acceptable in these countries is not as simple as it sounds. The explanations to be made span long geographical distances, the positive attitude of people toward new technologies, and rapid economic growth (Pantzar, 1996:136-137). While internet banking services are numerous in number, there is not enough evidence of Nigerian consumers' proper acceptance and a likely intention to continue to use the services (Awe, 2009). What then are the factors that influence Nigerian Internet banking users towards continued usage? In what ways are the users thinking about using internet banking to exploit new opportunities? These among others are the questions that generated curiosity to embark on this study because for us to accept that internet banking has fully gained prominence in Nigeria, customer's attitude towards use, system and service quality, perceived risk, perceived use and perceived usefulness need to be validated.

\section{Research Model}

Seven constructs made up the research model for the study. Three each were from Technology Acceptance Model (TAM) Davis (1989) and literature review while the last one was from the Delone \& McLean model (2004). The seven constructs were: attitude, perceived ease of use, perceived usefulness, system and service quality, perceived risk, perceived trust, organizational reputation and intention to use online banking.

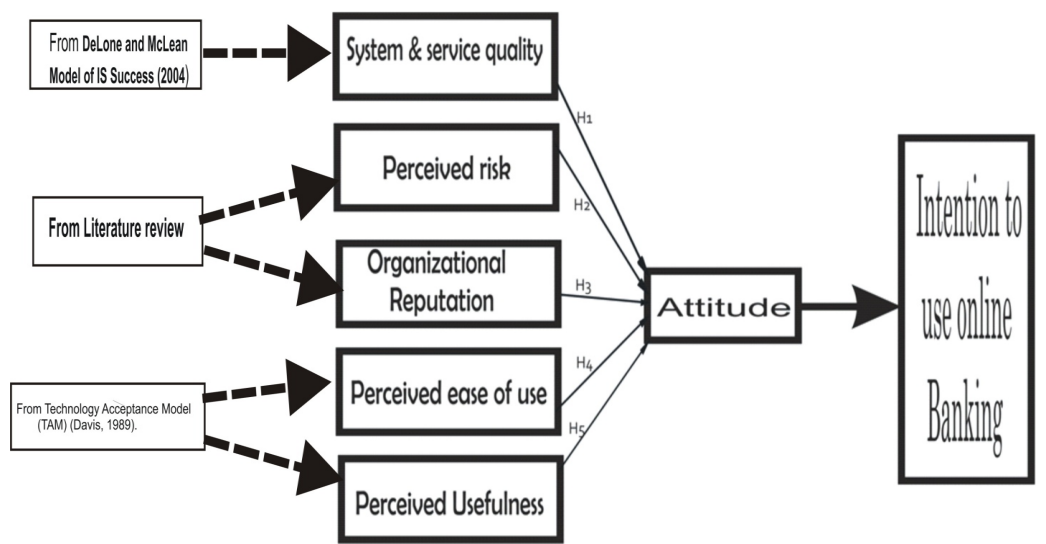

Figure 1: Research Model

\section{Research Hypotheses}

Based on a review of theories used in existing studies, a research framework was formulated consisting of the following constructs: system and service quality, perceived risk, organization reputation, perceived ease of use and perceived usefulness, attitude and intention to use. The first five constructs are independent variables while attitude is a dependent variable. Attitude is also an 
independent variable to intention to use. Five hypotheses are hereby formulated based on the constructs as follows:

System and service quality: According to DeLone and McLean, (2004) one of the most studied dimensions of IS success is system and service quality. It refers to measures of the information processing system itself, basically how well the hardware and the software work together. System quality has been operationalized in many ways in the IS literature, but some of the most relevant are convenience of access, flexibility of system and service, integration of system and service, response time (Bailey and Pearson, 1983); reliability, response time, ease of use, ease of learning (Belardo et al. 1982); and perceived usefulness of IS (Franz and Robey 1986). The first hypothesis, which is based on system and service quality construct is formulated as follows:

\section{$\mathrm{H}_{01}$ : System and service quality have no significant relationship with users' attitude to- wards internet banking.}

Perceived Risk: Using applications involving the use of Internet entails some risks. Perceived risk in the field of e-banking can be defined as: "the potential for loss in the pursuit of a desired outcome of using e- banking services" (Pavlou, 2003 and Featherman and Pavlou, 2002). The perception of the relatively high risk associated with performing financial transactions via electronic means may hinder users (Kamel, Hassan, and Hilgert, 2003).The effect of perceived risk on adoption and post adoption of e-banking was supported by Jaruwachirathanakul and Fink, (2005); Kolodinsky et al. (2004); Lin (2008); and Vatanasombut et al. (2008). The second hypothesis, which is based on the perceived risk construct is formulated as follows:

\section{$\mathrm{H}_{02}$ : There is no significant relationship between users' perceived risk and attitude towards internet banking.}

Organization Reputation: all the adoption model (like TAM, theory of planned behaviour (TPB), and theory of reasoned action (TRA)) were developed for studying technology adoption in developed countries, however, technology adoption in developed countries might be different from those of developing countries as the challenges are different in various contexts (Molla and Licker, 2005). Considering Technology-Organization-Environment (T-O-E) framework by Tornatzky and Fleischer (2009), three factors are important for any technology or innovation adoption diffusion process: technology context, organizational context and environmental context. Technology context includes both internal and external technologies applicable for firm. Organizational context includes resources (capital and human), organizational scope and size. Environment context includes both the direct and indirect roles of competitors, industry associations, and the governments. Following this, Tan and Teo (2000) adopted organization reputation as one of the factors for determining adoption of Internet banking in Singapore. Their investigations revealed the need for organization reputation. Thus, the third hypothesis, based on organization reputation construct, is formulated as follows:

\section{$H_{03}$ : There is no significant relationship between users' perceived organizational reputation} and attitude towards internet banking.

Perceived ease of use: Perceived ease of use refers to "the degree to which a person believes that using a particular system would be free of effort"(Davis et al., 1989; Mathieson, 1991). The effect of perceived ease of use on adoption of and intention to continue using Internet banking services was supported in a number of studies (Adesina and Ayo, 2010; Al- Sukkar and Hassan, 2005; ElKasheir and Salter, 2009; Kamel, Hassan, and Hilgert, 2003; Kolodinsky et al., 2004; Muniruddeen 2007; Ravi and Turban, 2007; and Vatanasombut et al., 2008). Thus, the fourth hypothesis, based on perceived ease of use construct is formulated as follows: 


\section{$H_{04}$ : There is no significant relationship between users' perceived ease of use of internet banking and attitude towards using it.}

Perceived usefulness: perceived usefulness refers to "the degree to which a person believes that using a particular system would enhance his or her job performance"(Davis et al., 1989). A number of studies have found perceived usefulness to affect adoption of and intention to continue to use Internet banking services (Adesina and Ayo, 2010; Al-Sukkar and Hassan, 2005; Kamel, Hassan, and Hilgert, 2003; Kolodinsky and Hogarth, 2001; Kolodinsky, et al., 2004; Ravi and Turban, 2007; and Vatanasombut et al., 2008). The fifth hypothesis which is based on perceived usefulness construct is formulated as follows:

\section{$H_{05}$ : There is no significant relationship between users' perceived usefulness of internet banking and attitude towards using it.}

\section{Methodology}

This study adopted the survey research design. The study location was Iwo town in Osun state, Nigeria. The population was 5, 555 internet banking users across the five banks in the town Wema Bank, Intercontinental Bank, Skye Bank, Sterling Bank and First Bank Plc. Stratified random sampling technique was used to select 596 internet banking users: ten per cent of internet banking users was selected from Wema bank, fourteen per cent from Intercontinental bank, fifteen per cent from Sterling bank, ten per cent from First bank Plc., while from Skye bank only four per cent of the users participated in the survey although $10 \%$ was targeted.

\section{Data Collection Instrument and Measures}

Questionnaire was the data collection instrument adopted for the study owing to its usefulness and suitability for collecting qualitative data over a large number of respondents. It has equally been used successfully in similar studies (Obasi, 2001; Abid and Noreen, 2008; Ahmad and Buttle, 2008; Olatokun and Igbinedion, 2009; Adeyinka, 2009; Burnham, 2010) and the extent of its reliability has been found to be high. The structured questionnaire was divided into two sections. Section A measured demographic characteristics of customers. Data collected from the customers include: age, gender, level of education and years of experience in using internet banking. Section B contained questions aimed at measuring the opinions of respondents on internet banking system and services quality, perceived risk, perceived usefulness of internet banking, perceived ease of use of internet banking, organizational (bank) reputation, users' intention to use internet banking services and their attitude towards internet banking usage. A 4-point Likert scale was used in designing the questions (Strongly Disagree $=1$, Disagree $=2$, Agree $=3$ and Strongly Agree=4). Appendix 1 presents a copy of the questionnaire.

Content validity was established by pre-testing the questionnaire among internet banking users in Ibadan, a Nigerian municipality using a randomly selected sample of 20 . The results of the pretest were used to modify the framing of some questions. Cronbach alpha reliability test was ran to determine the internal consistency of the multiple items scales. Cronbach's alpha was used in this study because every item was measuring an underlying construct (Leech and James, 2005). Table 1 presents the Cronbach alpha coefficient for the seven constructs. 


\section{Construct}

System and Service quality

Perceived Risk

Perceived Usefulness

Perceived Ease of use

Organizational Reputation

Intention to use

Attitude
Table 1: Reliability Test

$\begin{array}{cc}\text { Cronbach's Alpha } & \text { No. of Items } \\ 0.89 & 9 \\ 0.87 & 5 \\ 0.78 & 4 \\ 0.75 & 5 \\ 0.77 & 2 \\ 0.84 & 4 \\ 0.82 & 5\end{array}$

Table 1 shows the Cronbach's alpha for the items that made up the constructs. The alpha values indicate that the items that formed them have reasonable internal consistency reliability - being from 0.75 and above. The items which were deleted had alpha values that were either less than 0.3 or higher than 0.9. According to James and Ramaseshan (2009) items with alpha value over 0.9 are probably repetitious and deleting such items would help in getting better results in further analysis.

\section{Data Collection and Analysis}

Data were generated directly from the respondents by the researchers and two assistants who were recruited and trained in data collection strategies and ethics. The two assistants were from Bowen University, located in the heart of Iwo, the location of the study. Six-hundred copies of the questionnaire were administered but a total of 596 useable copies were returned and useful for data analysis giving $99.3 \%$ response rate. Only (4\%) of the targeted (10\%) of Internet banking users in Skye bank could be found. It was observed also that most of the customers who agreed to fill out the questionnaire were youths ( $19-30$ years of age). This probably might due to the fact that they were more patient than the older respondents.

Results of demographic profile of the respondents revealed that there were more male than female at $66.3 \%$ to $33.7 \%$. Majority of the respondents were between the ages of $19-30(53.5 \%)$, followed by those who were between the ages of $31-40$ (29.0\%). Apparently, a very small percentage $(3.4 \%)$ of the respondents was 18 years of age or less, followed by $(6.2 \%)$ who were above 50 years of age. Most of the respondents were students (50.2\%), civil servants (22.0\%) and those who claimed to be professionals (12.6\%). It was found that most of the users had less than 5 years experience $(72.8 \%)$, followed by users that had $6-10$ years' experience of using internet banking $(24.3 \%)$. Users having experience from $11-15$ years were a $(1.2 \%)$ followed by $16-19$ years $(1.5 \%)$. This result is in line with previous studies on internet banking, where users tend to be young and have at least secondary school education (Adesina and Ayo, 2010; Abid and Noreen, 2008; Al-Sukkar and Hassan, 2005; Casalo, Flavian, and Guinaliu, 2007; Kamel, Hassan, and Hilgert, 2003).

Analysis of data was based on 596 returned questionnaires. Responses from the questionnaire were coded, and Statistical Package for Social Sciences (SPSS) software was used for the analysis. Multi-level analysis was carried out on the data. At the first level, descriptive statistics (such as simple frequency table, mean, and standard deviation) was used to describe the demographic data about the respondents. Next, regression analysis was run to test the hypotheses with the level of significance fixed at 0.05 . 


\section{Results}

\section{Test of Hypotheses}

Results of the test of hypotheses are presented in Table 2 indicating the relationship between dependent and the predictor variables.

Table 2: Regression Analysis of the variables

\begin{tabular}{|c|c|c|c|}
\hline Predictor Variable & $\beta$ & t & Sig. Level \\
\hline Perceived Risk & .122 & 3.630 & .000 \\
\hline \multicolumn{4}{|c|}{ Dependent variable : Attitude } \\
\hline Predictor Variables & $\beta$ & $\mathbf{t}$ & Sig. Level \\
\hline Perceived Usefulness & .119 & 3.046 & .002 \\
\hline \multicolumn{4}{|c|}{ Dependent variable : Attitude } \\
\hline Predictor Variables & $\beta$ & $\mathbf{T}$ & Sig. Level \\
\hline Perceived ease of use & .206 & 5.698 & .000 \\
\hline \multicolumn{4}{|c|}{ Dependent variable : Attitude } \\
\hline Predictor Variable & $\beta$ & $T$ & Sig. Level \\
\hline System and service quality & .127 & 2.966 & .003 \\
\hline \multicolumn{4}{|c|}{ Dependent variable : Attitude } \\
\hline Predictor Variable & $\bar{\beta}$ & $\mathbf{T}$ & Sig. Level \\
\hline Organizational reputation & .167 & 4.316 & .000 \\
\hline \multicolumn{4}{|c|}{ Dependent variable : Attitude } \\
\hline Predictor Variable & $\beta$ & $\mathbf{T}$ & Sig. Level \\
\hline Intention to use & .323 & 7.139 & .000 \\
\hline
\end{tabular}

$\mathrm{H}_{01}$ : System and service quality have no significant relationship with users' attitude towards internet banking.

The results in Table 2 show that at $\mathrm{p}<0.05$, there is a positive and significant relationship between System and service quality and users' attitude to use internet banking. $(\mathrm{p}=.003, \beta=.127, \mathrm{t}=$ 2.966). Therefore, the null hypothesis was not accepted.

\section{$\mathrm{H}_{02}$ : There is no significant relationship between users' perceived risk and attitude towards internet banking.}

The result in Table 2 shows that at $p<0.05$, there is a positive and significant relationship between perceived risk and attitude to use internet banking $(\mathrm{p}=.000, \beta=.122, \mathrm{t}=3.630)$. Therefore, the null hypothesis was not accepted.

$\mathrm{H}_{03}$ : There is no significant relationship between users' perceived organizational reputation and attitude towards internet banking.

From Table 2, the results show that at $\mathrm{p}<0.05$, there is a positive and significant relationship between users' perceived organizational reputation $(p=.000, \beta=.167, t=4.316)$ and their attitude to using internet banking. Therefore, the null hypothesis was not accepted. 


\section{$\mathrm{H}_{04}$ : There is no significant relationship between users' perceived ease of use of internet banking and attitude towards using it.}

From Table 2 , the results show that at $\mathrm{p}<0.05$, there is a positive and significant relationship between users' perceived ease of use of internet banking and their attitude to use it. $(p=.000, \beta$ $=.206, \mathrm{t}=5.698$ ). Therefore, the null hypothesis was not accepted.

\section{$H_{05}$ : There is no significant relationship between users' perceived usefulness of internet banking and attitude towards using it.}

The results in Table 2 show that at $p<0.05$, there is a positive and significant relationship between users' perceived usefulness of internet banking and their attitude to use it $(\mathrm{p}=.002, \beta=.119, \mathrm{t}=$ 3.046).Therefore, the null hypothesis was not accepted.

\begin{tabular}{lcl} 
Variable & Table 3: Summary of Values \\
Beta & p-value \\
\hline Perceived Risk & 0.136 & $\mathrm{p}<0.05$ \\
Perceived Usefulness & 0.127 & $\mathrm{p}<0.05$ \\
Perceived ease of use & 0.233 & $\mathrm{p}<0.05$ \\
Organization reputation & 0.163 & $\mathrm{p}<0.05$ \\
System and service quality & 0.119 & $\mathrm{p}<0.05$ \\
\hline
\end{tabular}

Table 4: Hypotheses results

$\begin{array}{lr}\begin{array}{l}\text { Null Hypotheses } \\ \mathrm{H}_{01} \text { : System and service quality have no significant relationship with users' } \\ \text { attitude towards intention to use internet banking }\end{array} & \begin{array}{l}\text { Decision } \\ \text { Rejected }\end{array} \\ \mathrm{H}_{02} \text { : There is no significant relationship between users' perceived risk and } & \text { Rejected } \\ \text { attitude towards their intention to use internet banking } & \\ \mathrm{H}_{03}: \begin{array}{r}\text { There is no significant relationship between users' perceived organizational Rejected } \\ \text { reputation and attitude towards their intention to use internet banking. }\end{array} & \\ \mathrm{H}_{04}: \begin{array}{l}\text { There is no significant relationship between users' perceived ease of use } \\ \text { of internet banking and attitude towards their intention to use it. }\end{array} & \text { Rejected } \\ \mathrm{H}_{05}: \begin{array}{l}\text { There is no significant relationship between users' perceived usefulness of } \\ \text { internet banking and attitude towards their intention to use it }\end{array} & \text { Rejected } \\ \end{array}$

Table 4 shows the results of the hypothesis tested against the $p$ values that were obtained from the results above. These values are shown summarily below.

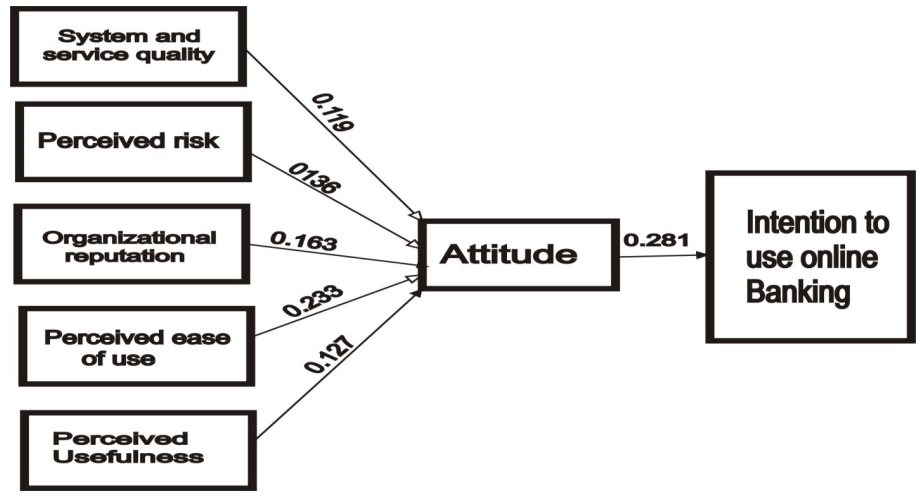

Fig 2: Resultant Model 


\section{Discussion}

System and service quality was found to have a significant positive effect on the attitude towards using internet banking. The construct had the lowest impact on attitude towards intention to use internet banking. This could be attributed to the many benefits derived from internet banking that have led users to prefer it to traditional way of banking. The significant contribution of system and service quality to the DeLone and McLean information success theory is consistent with previous research involving information system acceptance. DeLone and McLean (2004) found that system and service quality both affect use and user satisfaction, both being antecedents of individual impact, and this individual impact should ultimately affect organizational impact. Also, Oyelowo (2008) found system and service quality to be significant with user satisfaction and individual impact. Wang and Young (2003) found the significant influence of system and service quality on the intention to use Internet banking very high and endorsed the construct as a major determinant of users' intention to use new information system. Celik (2008) found that system and service quality had the principal influence on users attitude to adopt internet banking services.

The contribution of perceived risk was found to be positively significant in this study. Its significant contribution to information system acceptance has been reported in other studies. Tan and Teo (2000) found perceived risk as one of the factors influencing intentions to adopt internet banking services while analyzing the adoption level of internet banking in Taiwan. Westland (2002) found perceived risk to be significant in his study and concluded that, "transaction risk occurs when online markets fail to assure that service will be delivered with adequate quality; slow response time after the Internet interaction leads to a delay of service delivery and causes customers to be unsure that the transaction was completed".

Organizational reputation had the second highest influence on attitude towards the use of internet banking. Its significant influence demonstrates the extent to which organizational reputation can affect users' attitude and continued use of internet banking services. The contribution of organizational reputation has been in line with the findings of other studies. Oyinlola (2009) suggested that the rate of adoption of a new innovation such as internet banking is related to organizational reputation: the greater the perceived organizational reputation, the faster the adoption. Secondly, the desire to improve organizational reputation in financial institutions is seen to be an enabler for users technological acceptance change. He further suggested that if internet technology can be used to improve organizational reputations and performance, a bank would be able to gain advantage in a competitive environment.

Perceived ease of use had the highest impact and influence on users' attitude to adopt and use internet banking. This suggests that internet banking makes it easier for users to carry out their tasks. This has also been highlighted in previous studies. According to Adesina and Ayo (2010) perceived ease of use has an important contribution towards information system and understanding its usage and acceptance behaviour of users. Al- Sukkar and Hassan (2005) applied the Technology Acceptance Model in two countries with different cultures using perceived ease of use as their major variable and found that perceived ease of use of information system played an important role in influencing attitude toward users' choice of communication media. Ravi and Turban (2007) also investigated the effect of gender difference on acceptance of information system and to determine that gender significantly moderates the effects of perceived usefulness and perceived ease of use. They found that men were more affected by perceived usefulness, while women were more affected by perceived ease of use and subjective norms. Similarly Moon and Kim (2001) applied Technology Acceptance Model in the context of Internet usage, differentiating duties into entertainment and job-related task. They found that the significant factors affecting internet usage depended on its perceived ease of use. 
Perceived usefulness also had impact on attitude towards using internet banking. This finding suggests that people adopt and use internet banking when the degree of its usefulness would enhance their job performance. The significant contribution of perceived usefulness to information success theory and TAM model is also emphasized in other studies. According to Hogarth (2001), perceived usefulness is an important construct that influence customer use of electronic banking. He mentioned that by giving different options to the customer like mobile banking, SMS banking, bill payments, exchange rates, news and events can attract and influence customer to use electronic banking facilities. Moon and Kim (2001) used the construct to predict attitude in a survey of 152 graduate students of management in Korea. Their findings showed that perceived usefulness is a key determinant of user acceptance of information technology. The results of Moon and Kim (2001) revealed that perceived usefulness had a more significant effect on attitude than perceived risk in the WWW context and it equally has more significant effect on attitude than system and service quality. It is therefore noteworthy for skeptics of internet banking to examine the attributes of the model in the light of their local situation to see how they could improve on their deployment of internet banking.

\section{Conclusions and Recommendations}

This study presented an empirical analysis of internet banking adoption and use among users in Iwo, Osun state, Nigeria. The research model evaluated system and service quality, perceived risk, perceived usefulness, perceived ease of use and organisation reputation, as antecedent to behavioural intention to continue using internet banking solution. Model construct for all the hypotheses were found to be significantly related to attitude and continued use of internet banking services. The findings revealed that perceived ease of use and perceived usefulness are not only antecedent to internet banking acceptance, they are also factors to retain customers to the use of internet banking system such as system and service quality, organizational reputation and perceived risk.

These findings have the following practical and policy implications: undertaking an investigation on technology acceptance could enrich the research centers in Nigeria, providing a standard of research that could receive wider recognition. It will help bank managers to identify factors that influence the adoption and continued use of internet banking so as to increase its use and encourage the general acceptance of new IT services. Also, from a theoretical perspective, the study provides new information about consumer behaviour in a rapidly changing financial services industry. In addition, consumer perceptions and reactions toward information technology and banking technology is a significant area to which this study has contributed. Knowing consumer behaviour in the context of internet banking will provide a relatively important theoretical background for future research in the area of electronic business. Moreover, the results have provided a good basis for future marketing strategies concerning the development of electronic banking services. From the researchers' point of view, the winners in this field will be those institutions with appropriate knowledge of not only the technological achievements and developments but also those with a profound understanding of their customers.

Based on the findings, it was recommended that banks should try to improve on their system(s) and service(s) quality. They can do this by making the interface of online banking technologies user friendly as much as possible and also adopt state-of-the-art technology for effective and efficient internet banking transactions; providing newer models and system of internet banking services that will make users' transactions easier and more enjoyable; establishing a link with the customers to determine their requirements that can lead to successful electronic banking solutions; focusing on their needs and using the right technology to achieve goals, rather, than acquiring technology of internet banking because other banks have it. They should also employ the best means of drawing the publics' attention to their product and services and also convince them of 
the efficiency of the organization which could go a long way in sustaining internet banking use. All these measures are expected to aid in improving system and services quality, which would lead to users' satisfaction and finally, positively affect the attitude of adopters towards internet banking usage. The Central Bank of Nigeria should stipulate standards for banks to follow to avoid making Nigerian banking sector a dumping ground for outdated technological infrastructure and counter legal and security threats posed to net banking and e-commerce to enhance growth in the banking industry. In addition, it is recommended that government should participate in ensuring that the telecommunication industry is subsidized to reduce or remove avoidable costs of implementing internet banking in the country. Future studies could compare factors influencing adoption decisions, the criteria for selecting an online banking service, and the types of products and services perceived to be useful across cultures. Also, testing the research model in a longitudinal study among different types of adopters could be studied in future.

\section{References}

Abid, H., \& Noreen, U. (2008). Ready to E-bank: An exploratory research on adoption of e-banking and ereadiness in customers among commercial banks in Pakistan. Spider, 31(2), 1-31.

Adesina, A. A. \& Ayo, C. K. (2010). An empirical investigation of the level of users' acceptance of Ebanking in Nigeria. Journal of Internet Banking and Commerce, 15(1).

Adeyinka, D. A. (2009). Perceived usefulness, ease of use, and usage of information technology: A replication. MIS Quarterly, 16(2), 227-247.

Ahmad, R., \& Buttle, F. (2008). Retaining telephone banking customers at Frontier Bank. International Journal of Bank Marketing, 20 (1), 5-16.

Al- Sukkar, A., \& Hassan, H. (2005). Toward a model for the acceptance of internet banking in developing countries. Information Technology for Development, 11(4), 381- 398.

Appiah, A., \& Agyemang F. (2005). Electronic retail payment systems: User acceptability and payment problems in Ghana. School of Management Business Administration, Blekinge Institute of Technology, Sweden.

Ayobami, F. K (2009). The key determinants of Internet banking service quality: A content analysis. International Journal of Bank Marketing, 19(7), 276-291.

Bailey, J. E., \& Pearson, S. W. (1983). Development of a tool for measuring and analyzing computer user satisfaction. Management Science, 29(5), 530-545.

Belardo. S., Karwan, W., \& Wallace, W. (1982). DSS Component design through field experimentation: An application to emergency management. Proceedings of the Third International Conference on Information System pp. 93-108. AnnArbor

Burnham, B. (2010). The Internet's impact on retail banking. Booz-Allen Hamilton, pp. 1-10

Business Day Online (2011). E-banking adoption and use in Nigeria. Retrieved 23rd April, 2011 from http://www.businessdayonline.com/

Casalo, L. V., Flavian, C., \&. Guinaliu, M. (2007). The role of security, privacy, usability and reputation in the development of online banking. Online Information Review, 31(5), 583-602.

Celik, M. (2008). Man-machine planning systems: A cognitive style examination of interactive decision making. Journal of Accounting Research, 15(1), 138-153.

Cooper, W. K ( 1992). Consumer resistance and intention to use Internet banking service. Proceedings of the EBRF Conference, Jyväskylä, Finland, September 25-27, 2007.

Davis, V. K. (1989). Technology use and performance: A field study of broker workstations. Decision Sciences, 30(2), 291-311. 
DeLone, W., \& McLean, E. ( 2004). Measuring e-commerce success: Applying the Delone\& Mclean Information Systems Success Model. International Journal of Electronic Commerce, 9(1), 31-47.

El-Kasheir, S., \& Salter, G. (2009). A motivational view of information systems success: A reinterpretation of Delone \& Mclean's Model. Proceedings of the 6th Australasian Conference on Information Systems, 119-140.

Featherman, A. \& Pavlov, D. (2002). Factors influencing electronic data interchange success. $A C M S I G-$ MIS Database, 27(1), 45-57.

Franz, P. S., \& Robey, I. (1986). A comparison of the theory of planned behaviour and the theory of reasoned action. Personality and Social Psychology Bulletin, 18, 3-9.

Hogart, D. (2001). Differences in public web sites: The current state of large US firms. Journal of Electronic Commerce Research, 1(3), 94-105.

Internet World Status. (2009). Easy money. Information Society, 1(5), 16-30. Retrieved 15 February 2011 from http://www.2.cio.com/metrics/2003/metric537.html

James, C., \& Ramaseshan, B. (2009). The role of customer-contact personnel in the marketing of retail bank's services. International Journal of Retail and Distribution Management, 22(5), 29-34.

Jaruwachirathanakul, B., \& Fink, D. (2005). Internet banking adoption strategies for a developing country: The case of Thailand. Internet Research, 15(3), 295- 311.

Kamel, S., Hassan, A., \& Hilgert, A. (2003). Electronic banking in Egypt. The International Journal of Bank Marketing, 26(6), 406-423.

Kolodinsky, J. M., Hogarth, J. M., \& Hilgert, M. (2004). The adoption of electronic banking technologies by US consumers. The International Journal of Bank Marketing, 22(4), 238-259.

Kolawole, A., \& Kayode, O. (2008). The lagging development of small business Internet banking in Nigeria. Journal of Small Business Management, 40(1), 22-40, 51-57.

Leech, K., \& James, B. (2005). An exploratory study to identify the critical factors affecting the decision to establish internet-based inter organizational information systems. Information and Management, 41(6), 697-707.

Lin, W. (2008). Construction of on-line consumer behaviour models: A comparative study of industries in Taiwan. International Journal of Commerce and Management, 18(2), 123-149.

Mathieson, K. (1991). Predicting user intentions: Comparing the technology acceptance model with the theory of planned behaviour. Information Systems Research, 2, 173-191.

Muniruddeen, S. T., \& McKinney, R. H. (2010). Extending the technology acceptance model and tasktechnology $\mathrm{ft}$ model to consumer e-commerce. Journal of Information Technology, Learning and Performance, 22(1), 26-30.

Moon, Z., \& Kim, M. T. (2001). Internet-based e-banking and consumer attitudes: An empirical study. Information \& Management, 39(4), 283-295.

Molla, A., \& Licker, P. (2005). E-commerce systems success: An attempt to extend and respecify the Delone and Mclean Model of IS success. Journal of Electronic Commerce Research, 2(4), 131-141.

Obasi, M. A., \&Zubair, W. T. (2001). E-Security issues in Pakistan. Spider, 1(August), 29.

Oyelowo, F. K (2008). Determinants of user acceptance of internet banking: An empirical study. Int. J. Service. Industrial Management, 14(5), 501-519.

Oyinlola, A. M. (2009). Online banking: A field study of drivers, development challenges, and expectations. International Journal of Information Management, 21(4), 213-225.

Olatokun, W.M., \& Igbinedion, L. J. (2009). The adoption of automatic teller machines in Nigeria: An application of the theory of diffusion of innovation. Issues in Informing Science and Information Technology, 6, $380-387$. 
Pavlou, P. A. (2003). Consumer acceptance of electronic commerce: Integrating trust and risk with the technology acceptance model. International Journal of Electronic Commerce, 7(3), 101-134.

Pantzar, M. (1996). Kuinka teknologia kesyntyy. Kulutuksen tieteestä kulutuksen taiteeseen. (How technology is domesticated [in Finnish]) Tammi Press, Helsinki.

Ravi, M., \& Turban, E. (2007). A trust model for consumer Internet shopping. International Journal of Electronic Commerce, 6(1), 75-91.

Salem, F. K. (2004). Alternative monies and the demand for media of exchange. Journal of Money, Credit and Banking, 28, 942-960.

Tan, M., \&Teo, T. S. H. (2000). Factors influencing the adoption of Internet banking. Journal of the AIS, $1(5), 1-42$.

Tajudeen, W. U., Ayobami, C. K., \& Babajide, D. O. (2006) Designing a reliable E-payment system: Nigeria. A case study. Journal of Internet Banking and Commerce, 11(2).

Tornatzky, A., \& Fleischer, D. (2009). The adoption of direct banking services. Journal of Marketing Management, 13(8), 791-811.

Vatanasombut, B., Igbaria, M., Stylianou, A. C., \& Rodgers, W. (2008). Information systems continuance intention of web-based applications customers: The case of online banking. Information \& Management, 45(7), 419-428.

Westland, P. (2002). Why do people use information technology? A critical review of the technology acceptance model. Information \& Management, 40, 191- 204.

Williamson, M. F. (2006). Monetary policy implications of digital money. Kyklos, 51, 89117.

William, M. T., \& Appiah, N. O. (2005). Validation study on marketing mix and customer satisfaction in technology-enabled services: Evidence from Nigerian GSM Market. Nigerian Journal of Management Technology, 1(1), 1-13.

Woodruff, D. F. (2008). Electronic money: A challenge to the sovereign state? Journal of International Affairs, 51, 387-409.

\section{Appendix. Questionnaire}

Dear Respondent.

This study is titled "Influence of individual, organizational and system factors on attitude of online bankers" and it is meant to investigate the factors that influence the attitude of online banking users in Osun state. Kindly fill out your responses as candidly as possible. The data you provide will be treated in confidence and used only for academic purposes. Thank you for your anticipated cooperation.

(The Researchers)

Email: woleabbeyolatokun@yahoo.co.uk pastorjoe4u@rocketmail.com

SECTION A: DEMOGRAPHIC CHARACTERISTICS

(Please tick the most suitable option or fill the space provided)

\begin{tabular}{|c|c|}
\hline Gender & Male $\quad[\quad] \quad$ Female \\
\hline Age & 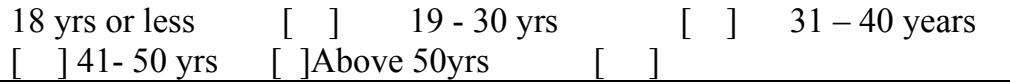 \\
\hline Occupation & 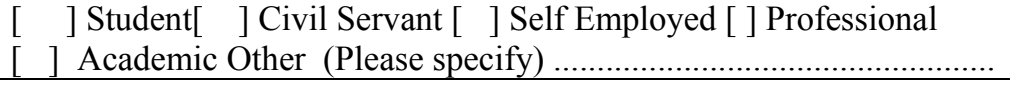 \\
\hline Education & 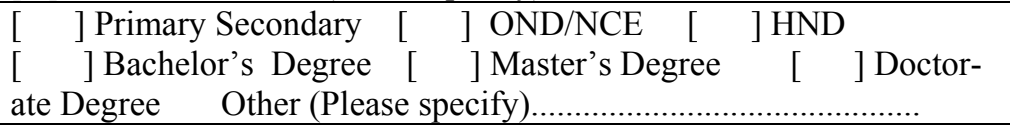 \\
\hline $\begin{array}{l}\text { Years of experience of } \\
\text { using internet banking }\end{array}$ & $\begin{array}{l}\text { Less than five (5) years [ ] } 6-10 \text { years [ ] } 11-15 \text { years [ ] } \\
16-19 \text { years [ ]20 years and above [ ] }\end{array}$ \\
\hline
\end{tabular}


SECTION B: Please indicate to which extent you agree with each of the following statements NOTE: 1 = Strongly Disagree, 2=Disagree, 3=Agree , 4 =Strongly Agree SYSTEM AND SERVICE QUALITY

The speed of login of your account is fast

The website is available in the language you can understand

The bank takes care of problems properly and compensate for the prob-

lems they create

The web pages do not freeze after you have put in all your information

Information content and text are easy to understand

The bank is willing to help customers, provide appropriate information and prompt service

Your bank site performs the service right at the first time you log in

The bank's site provides a confirmation of the service ordered quickly

Links are problem-free, accurate and the pages download quickly

PERCEIVED RISK

I feel secure sending sensitive information during internet banking transaction

I can always rely on internet banking for my banking activities

My bank provides financial security and confidentiality

The banks site has unrestricted access to all financial information

I trust my bank's Internet banking site

PERCEIVED USEFULNESS

Using internet banking enables me to accomplish my tasks more quickly

Overall, I find using internet banking to be cheaper

Using internet banking enables me to carryout transactions with ease

Internet banking allows me to manage my finance more effectively

PERCEIVED EASE OF USE

Overall, I find the use of the internet banking services easy

It is easy for me to become skillful in the use of the internet banking services

Using internet banking would make it easier for me to carry out my tasks

I find it easy to do what I want to do with internet banking Interaction with internet banking does not require much mental effort

ORGANIZATIONAL REPUTATION

Do you think that the infrastructure provided by your bank is appropriate to utilize internet banking efficiently?

Does your bank adopt the latest technology and standards for internet banking?

\section{INTENTION TO USE}

I will continue to use internet banking services

I believe that internet banking will be more relevant in the future

I still prefer to use internet banking than withdraw money from cashier in a bank

The low risk involved in using internet banking will enable me to continue to use it

ATTITUDE

Using internet banking is a good idea

Using internet banking is pleasant

It would be desirable to use internet banking

Using internet banking is a wise idea

Using Internet banking fits well with the way I like to manage my finance. 


\section{Biographies}

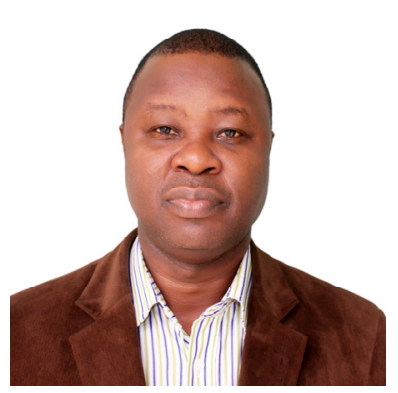

Dr Wole Michael Olatokun holds Master and $\mathrm{PhD}$ degrees in Information Science from the University of Ibadan, Nigeria. He teaches information science at the Africa Regional Centre for Information Science (ARCIS) in the same university. His research interests include: information and communication technology (ICT) policy issues, Social Informatics, knowledge management, ICT for development, indigenous knowledge systems and e-governance. He can be contacted at: woleabbeyolatokun@yahoo.co.uk

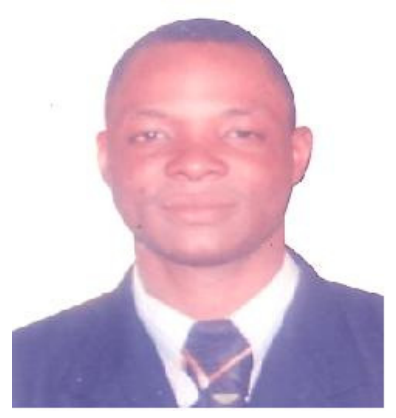

Owoeye Joseph Olalekan holds Bachelor's degree in Business Administration obtained from Bowen University and a Master of Information Science (MInfSc) degree obtained from Africa Regional Centre for Information Science (ARCIS), University of Ibadan, both in Nigeria. He also holds Diplomas in Computer Science and Web Content Development; Oracle Certification and Chattered in Management (Nigeria Institute of Management (NIM)). Currently, he works as Control Room Officer at XNet Security Technologies Ltd, Lagos, Nigeria. He can be contacted through: pastorjoe4u@rocketmail.com/ mypastorjoe4u@gmail.com 